\title{
The Effects of Excess Aluminum on Mechanical Properties of Mn-Mo, Mn-Mo-Ni and Mn-Mo-Ni-Cr Steels with Regard to Solute Interactions*
}

\author{
By Hidesato MABUCHI** and Hitoji NAKAO***
}

\section{Synopsis}

Mechanical properties have been studied through the changes of $\mathrm{Al}$ and $\mathrm{N}$ contents in $\mathrm{Mn}-\mathrm{Mo}, \mathrm{Mn}-\mathrm{Mo}-\mathrm{Ni}$ and $\mathrm{Mn}-\mathrm{Mo}-\mathrm{Ni}-\mathrm{Cr}$ steels with regard to solute interactions between alloying elements by means of Charpy $V$-notch impact tests, tensile tests and microscopical observations.

The results show that the low-temperature toughness is anomalously deteriorated in $\mathrm{Mn}-\mathrm{Mo}$ and $\mathrm{Mn}-\mathrm{Mo}-\mathrm{Ni}$ steels but indistinctly related in $\mathrm{Mn}-\mathrm{Mo}-\mathrm{Ni}-\mathrm{Cr}$ steel by an increase of excess $\mathrm{Al}$. It is also shown that the tensile strength is remarkably increased, slightly increased and not increased at all by an increase of excess $\mathrm{Al}$ in $\mathrm{Mn}-\mathrm{Mo}, \mathrm{Mn}-\mathrm{Mo}-\mathrm{Ni}$ and $\mathrm{Mn}-\mathrm{Mo}-\mathrm{Ni}-\mathrm{Cr}$ steels, respectively.

\section{Introduction}

Mechanical properties in low-alloy steels can be improved by the control of solute interactions between alloying elements and impurities.

Very little attention has been paid to the influence of solute interactions on the mechanical properties in practical steel, which is multi-component, due to the complication of microsegregation and due to the incompletion of thermodynamics in the solid-phase compared with the liquid-phase. However, the influence of solute interactions may be of great importance in understanding the effects of micro-alloying elements on the diagram of continuous-cooling-transformation, and the segregation of alloying elements and impurities at grain boundaries.

The classical studies in the foregoing fields have been carried out on the tendency to form carbides of various alloying elements for $\mathrm{Fe}-\mathrm{C}-\mathrm{M}$ systems by Bain, ${ }^{1)}$ on the up-hill diffusion of carbon for $\mathrm{Fe}-\mathrm{C}-\mathrm{Si}$ system by Darken, ${ }^{2}$ and on the banded structure of ferrite and pearlite by previous investigators. ${ }^{3,4)}$ It should be noted that the above studies have been associated with the influence of relatively high-alloying elements for $\mathrm{Fe}-\mathrm{C}-\mathrm{M}$ systems.

It was recently shown by Mabuchi et al. ${ }^{5-7)}$ that the low-temperature toughness in an A302C steel is deteriorated by adding a small amount of excess $\mathrm{Al}$ (only about $0.010 \%$ ) due to the change of the microstructure from fine ferrite to coarse upper bainite because of $\mathrm{Al}$ partitioning in bainitic ferrite and because of $\mathrm{G}$ enrichment in retained austenite left between bainitic ferrite during continuous-coolingtransformation through a repulsive force between Al-C.

Later, it is demonstrated by Mabuchi and McMahon $^{8,9)}$ that both temper embrittlement and hydrogen embrittlement in an HY 130 steel are essentially governed not by McLean's equilibrium segregation but by the segregation due to the resultant interactions of repulsive forces between $\mathrm{Si}-\mathrm{P}$, $\mathrm{Si}-\mathrm{N}$ and $\mathrm{Si}-\mathrm{Al}$, and of attractive forces between $\mathrm{Ni}-\mathrm{Si}, \mathrm{Ni}-\mathrm{Al}$ and $\mathrm{Si}-\mathrm{Mn}$ during ageing at $480{ }^{\circ} \mathrm{C}$ up to $1000 \mathrm{~h}$.

In order to elucidate this mechanism further with regard to effects of excess $\mathrm{Al}$ on mechanical properties, Mn-Mo (A302B), Mn-Mo-Ni (A302C) and Mn-Mo$\mathrm{Ni}-\mathrm{Cr}$ (A302C-Cr Mod.) steels have been studied in terms of changes in $\mathrm{Al}$ and $\mathrm{N}$ contents with the assistance of ideas on solute interactions between alloying elements and on partitioning.

\section{Experimental Procedures}

The Mn-Mo (A302B) steel was melted by means of a basic oxygen furnace and cast into 40-ton ingots. The ingots were rolled into $300 \mathrm{~mm}$ thick slabs and then rolled into $82 \mathrm{~mm}$ thick plates. The samples taken from the plates were austenitized as Hot Forming at $910^{\circ} \mathrm{C}$ for $6 \mathrm{~h}$ and then air cooled. They were stress relieved as Post Welding Heat Treatment (PWHT) at $605{ }^{\circ} \mathrm{C}$ for $7 \mathrm{~h}$ and then furnace cooled.

The Mn-Mo-Ni (A302C) steel was melted using an electric furnace and then cast into 70 to 90 -ton ingots. The ingots were forged into $500 \mathrm{~mm}$ thick slabs and then rolled into $143 \mathrm{~mm}$ thick plates. The samples were austenitized at $920^{\circ} \mathrm{C}$ for $4 \mathrm{~h}$ and then air cooled. They were stress relieved at $625^{\circ} \mathrm{C}$ for $17 \mathrm{~h}$ and then furnace cooled.

The Mn-Mo-Ni-Cr (A302C-Cr Mod.) steel was also melted by electric furnace and then cast into $100-$ ton ingots. The ingots were forged into $470 \mathrm{~mm}$ thick slabs and then rolled into $147 \mathrm{~mm}$ thick plates. The samples were austenitized at $920^{\circ} \mathrm{C}$ for $3 \mathrm{~h}$ and then air cooled. They were tempered at $670{ }^{\circ} \mathrm{C}$ for $3 \mathrm{~h}$ and then air cooled. They were stress relieved at $625^{\circ} \mathrm{C}$ for $22 \mathrm{~h}$ and then furnace cooled.

Hence, Larson-Miller Tempering Parameters of $\mathrm{Mn}-\mathrm{Mo}, \mathrm{Mn}-\mathrm{Mo}-\mathrm{Ni}$ and $\mathrm{Mn}-\mathrm{Mo}-\mathrm{Ni}-\mathrm{Cr}$ steels are 18.3, 19.2 and 19.5, respectively, by the following equation.

$$
T P=\mathcal{T}\left({ }^{\circ} \mathrm{K}\right)(20+\log t) \times 10^{-3}
$$

The compositions of Mn-Mo, Mn-Mo-Ni and $\mathrm{Mn}-\mathrm{Mo}-\mathrm{Ni}-\mathrm{Cr}$ steels are given as product analysis in Tables 1 to 3 , respectively. The three steels were all production heats, which had essentially the same com-

* Presented to the 92nd ISIJ Meeting, October 1976, at Tohoku Institute of Technology in Sendai. Manuscript received July 1, 1982. (C) 1983 ISIJ

** Plate Technical Dept., Head Office, Nippon Steel Corporation, Otemachi, Chiyoda-ku, Tokyo 100.

*** Nagoya Works, Nippon Steel Corporation, Tokaimachi, Tokai 476. 
positions except for excess $\mathrm{Al}$ in each steel. Excess $\mathrm{Al}$ is defined here by the following equation ${ }^{5,7)}$, since AlN precipitates would vary with heat treatment.

$$
\text { Excess } \begin{aligned}
\mathrm{Al} & =\mathrm{T} . \mathrm{Al}-\mathrm{Insol} . \mathrm{Al}-\mathrm{Al} \text { as } \mathrm{AlN} \\
& =\text { Sol.Al-27/14 } \mathrm{N} \text { as } \mathrm{AlN} \ldots
\end{aligned}
$$

Table 1. Composition of Mn-Mo steel. (Product analysis, wt \%)

\begin{tabular}{l|llll}
\multicolumn{1}{c|}{ Heat } & \multicolumn{1}{c}{$1 \mathrm{~A}$} & \multicolumn{1}{c}{$1 \mathrm{~B}$} & \multicolumn{1}{c}{$1 \mathrm{G}$} & \multicolumn{1}{c}{$1 \mathrm{D}$} \\
\hline $\mathrm{G}$ & 0.19 & 0.18 & 0.20 & 0.17 \\
$\mathrm{Si}$ & 0.26 & 0.25 & 0.24 & 0.24 \\
$\mathrm{Mn}$ & 1.45 & 1.43 & 1.46 & 1.46 \\
$\mathrm{P}$ & 0.017 & 0.019 & 0.014 & 0.019 \\
$\mathrm{~S}$ & 0.003 & 0.004 & 0.004 & 0.004 \\
$\mathrm{Cu}$ & 0.01 & 0.01 & 0.01 & 0.01 \\
$\mathrm{Ni}$ & 0.02 & 0.02 & 0.02 & 0.02 \\
$\mathrm{Cr}$ & 0.03 & 0.04 & 0.03 & 0.03 \\
$\mathrm{Mo}$ & 0.57 & 0.58 & 0.58 & 0.59 \\
$\mathrm{Sol.} \mathrm{Al}$ & 0.048 & 0.033 & 0.022 & 0.022 \\
$\mathrm{Sol.} \mathrm{N}$ & 0.0108 & 0.0116 & 0.0098 & 0.0108 \\
$\mathrm{~N}$ as AlN & 0.0102 & 0.0110 & 0.0090 & 0.0102 \\
Excess Al & 0.028 & 0.011 & 0.004 & 0.002 \\
\hline
\end{tabular}

Table 2. Composition of Mn-Mo-Ni steel. (Product analysis, wt\%)

\begin{tabular}{l|lllll}
\multicolumn{1}{c|}{ Heat } & $2 \mathrm{~A}$ & $2 \mathrm{~B}$ & $2 \mathrm{G}$ & $2 \mathrm{D}$ & \multicolumn{1}{c}{$2 \mathrm{E}$} \\
\hline $\mathrm{G}$ & 0.20 & 0.21 & 0.21 & 0.22 & 0.19 \\
$\mathrm{Si}$ & 0.22 & 0.21 & 0.24 & 0.22 & 0.27 \\
$\mathrm{Mn}$ & 1.40 & 1.38 & 1.49 & 1.38 & 1.41 \\
$\mathrm{P}$ & 0.008 & 0.007 & 0.007 & 0.009 & 0.008 \\
$\mathrm{~S}$ & 0.008 & 0.006 & 0.006 & 0.008 & 0.006 \\
$\mathrm{Cu}$ & 0.04 & 0.03 & 0.04 & 0.05 & 0.04 \\
$\mathrm{Ni}$ & 0.58 & 0.60 & 0.57 & 0.63 & 0.59 \\
$\mathrm{Cr}$ & 0.07 & 0.09 & 0.06 & 0.08 & 0.08 \\
$\mathrm{Mo}$ & 0.54 & 0.54 & 0.51 & 0.55 & 0.52 \\
$\mathrm{Sol.} \mathrm{Al}$ & 0.028 & 0.016 & 0.014 & 0.016 & 0.013 \\
$\mathrm{Sol.} \mathrm{N}$ & 0.0055 & 0.0051 & 0.0052 & 0.0061 & 0.0064 \\
$\mathrm{~N}$ as AlN & 0.0049 & 0.0044 & 0.0044 & 0.0055 & 0.0058 \\
Excess Al & 0.019 & 0.008 & 0.006 & 0.005 & 0.002 \\
\hline
\end{tabular}

Table 3. Composition of Mn-Mo-Ni-Cr steel. (Product analysis, wt \%)

\begin{tabular}{l|llll}
\multicolumn{1}{c|}{ Heat } & \multicolumn{1}{c}{$3 \mathrm{~A}$} & \multicolumn{1}{c}{$3 \mathrm{~B}$} & \multicolumn{1}{c}{$3 \mathrm{G}$} & \multicolumn{1}{c}{$3 \mathrm{D}$} \\
\hline $\mathrm{C}$ & 0.22 & 0.22 & 0.23 & 0.22 \\
$\mathrm{Si}$ & 0.25 & 0.24 & 0.23 & 0.24 \\
$\mathrm{Mn}$ & 1.46 & 1.50 & 1.44 & 1.43 \\
$\mathrm{P}$ & 0.008 & 0.008 & 0.007 & 0.009 \\
$\mathrm{~S}$ & 0.004 & 0.004 & 0.004 & 0.005 \\
$\mathrm{Cu}$ & 0.04 & 0.05 & 0.04 & 0.04 \\
$\mathrm{Ni}$ & 0.63 & 0.63 & 0.62 & 0.63 \\
$\mathrm{Cr}$ & 0.63 & 0.66 & 0.64 & 0.62 \\
$\mathrm{Mo}$ & 0.57 & 0.57 & 0.54 & 0.52 \\
$\mathrm{Sol.} \mathrm{Al}$ & 0.042 & 0.027 & 0.023 & 0.018 \\
$\mathrm{Sol} . \mathrm{N}$ & 0.0068 & 0.0058 & 0.0086 & 0.0076 \\
$\mathrm{~N}$ as AlN & 0.0060 & 0.0052 & 0.0080 & 0.0068 \\
Excess Al & 0.030 & 0.018 & 0.012 & 0.005 \\
\hline
\end{tabular}

In particular, supplemental product analysis for B was carefully carried out in investigating the influence of sol. B on the hardenability of the three steels, but nothing notable was found as reported previously. ${ }^{7}$

Charpy V-notch (GVN) impact tests and tensile tests were carried out for longitudinal specimens, taken from the quarter-thickness portion of samples, at various temperatures and at room temperature, respectively. The toughness of three steels was characterized by absorbed energies at $0{ }^{\circ} \mathrm{C}(v E o)$ and also by $50 \%$ Ductile-Brittle Fracture Appearance Transition Temperature (FATT) in GVN impact tests.

Optical microstructure and austenitic grain size by ASTM E112 were also observed.

The previous data of $\mathrm{Mn}-\mathrm{Mo}-\mathrm{Ni}$ steel ${ }^{7)}$ are employed to compare the present results of $\mathrm{Mn}-\mathrm{Mo}$ and $\mathrm{Mn}-\mathrm{Mo}-\mathrm{Ni}-\mathrm{Cr}$ steels.

\section{Experimental Results}

The results of tensile tests in $\mathrm{Mn}-\mathrm{Mo}, \mathrm{Mn}-\mathrm{Mo}-\mathrm{Ni}$ and $\mathrm{Mn}-\mathrm{Mo}-\mathrm{Ni}-\mathrm{Cr}$ steels are listed in Tables 4 to 6 , respectively. The excess $\mathrm{Al}$ of $\mathrm{Mn}-\mathrm{Mo}$ steel increased remarkably the tensile strength, and that of $\mathrm{Mn}-\mathrm{Mo}-$ $\mathrm{Ni}$ steel increased slightly the tensile strength, whereas that of $\mathrm{Mn}-\mathrm{Mo}-\mathrm{Ni}-\mathrm{Cr}$ steel did not increase the tensile strength at all, as is clearly depicted in Fig. 1.

It is also shown in Tables 4 and 5 that the yield strength increased and elongation decreased as the tensile strength increased through the increase of excess $\mathrm{Al}$ both in $\mathrm{Mn}-\mathrm{Mo}$ and $\mathrm{Mn}-\mathrm{Mo}-\mathrm{Ni}$ steels. In particular, it should be noted that the tensile strength of Mn-Mo steel is increased as a logarithmic function of excess Al.

The $v E o$ measured in $\mathrm{CVN}$ impact tests at $0{ }^{\circ} \mathrm{C}$ in $\mathrm{Mn}-\mathrm{Mo}, \mathrm{Mn}-\mathrm{Mo}-\mathrm{Ni}$ and $\mathrm{Mn}-\mathrm{Mo}-\mathrm{Ni}-\mathrm{Cr}$ steels are shown in Figs. 2 to 4, respectively, to compare the effects of excess $\mathrm{Al}$ in semi-logarithmic fashion. It is important to note that the $v E o$ of $\mathrm{Mn}-\mathrm{Mo}$ and $\mathrm{Mn}-$ Mo-Ni steels decreased very rapidly with an increase

Table 4. Result of tensile test in Mn-Mo steel.

\begin{tabular}{l|llll}
\multicolumn{1}{c|}{ Heat } & \multicolumn{1}{c}{$1 \mathrm{~A}$} & \multicolumn{1}{c}{$1 \mathrm{~B}$} & $1 \mathrm{C}$ & $1 \mathrm{D}$ \\
\hline Y.S. $\left(\mathrm{kgf} / \mathrm{mm}^{2}\right)$ & 56.1 & 52.0 & 44.1 & 41.6 \\
T.S. $\left(\mathrm{kgf} / \mathrm{mm}^{2}\right)$ & 69.8 & 65.2 & 62.6 & 59.2 \\
EI (\%) & 26 & 28 & 30 & 32
\end{tabular}

Table 5. Result of tensile test in Mn-Mo-Ni steel.

\begin{tabular}{c|lllll}
\hline Heat & \multicolumn{1}{|c}{$2 \mathrm{~A}$} & $2 \mathrm{~B}$ & \multicolumn{1}{c}{$2 \mathrm{C}$} & \multicolumn{1}{c}{$2 \mathrm{D}$} & \multicolumn{1}{c}{$2 \mathrm{E}$} \\
\hline Y.S. $\left(\mathrm{kgf} / \mathrm{mm}^{2}\right)$ & 50.8 & 47.7 & 50.8 & 49.6 & 46.1 \\
T.S. $\left(\mathrm{kgf} / \mathrm{mm}^{2}\right)$ & 63.8 & 61.5 & 62.1 & 63.6 & 61.5 \\
El $(\%)$ & 26 & 24 & 25 & 25 & 27 \\
\hline
\end{tabular}

Table 6. Result of tensile test in $\mathrm{Mn}-\mathrm{Mo}-\mathrm{Ni}-\mathrm{Cr}$ steel.

\begin{tabular}{c|llll}
\hline Heat & 3A & 3B & $3 \mathrm{C}$ & $3 \mathrm{D}$ \\
\hline Y. P. $\left(\mathrm{kgf} / \mathrm{mm}^{2}\right)$ & 55.9 & 53.4 & 54.6 & 53.9 \\
T.S. $\left(\mathrm{kgf} / \mathrm{mm}^{2}\right)$ & 70.0 & 67.7 & 69.5 & 69.5 \\
El (\%) & 25 & 26 & 22 & 27 \\
\hline
\end{tabular}


of excess $\mathrm{Al}$, and that the slope of the former was two times higher than that of the latter as a function of $\log$ excess $\mathrm{Al}$, whereas the $v E o$ of $\mathrm{Mn}-\mathrm{Mo}-\mathrm{Ni}-\mathrm{Cr}$ steel seems to be almost independent of excess $\mathrm{Al}$ in the present range as discussed later.

Figures 5 to 7 show the correlation of the FATT in CVN impact tests with excess $\mathrm{Al}$ in $\mathrm{Mn}-\mathrm{Mo}, \mathrm{Mn}-$ $\mathrm{Mo}-\mathrm{Ni}$ and $\mathrm{Mn}-\mathrm{Mo}-\mathrm{Ni}-\mathrm{Cr}$ steels, respectively. It is obviously shown that the FATT was quickly lowered as the excess $\mathrm{Al}$ was decreased both in $\mathrm{Mn}-\mathrm{Mo}$ and Mn-Mo-Ni steels, and that the slope of the former was higher than that of the latter. However, it is also noted that the FATT of Mn-Mo steel seems to be 20 to $30^{\circ} \mathrm{C}$ lower than that of $\mathrm{Mn}-\mathrm{Mo}-\mathrm{Ni}$ steel, since the former had the cooling rate of $10^{\circ} \mathrm{C} / \mathrm{min}$ in normalizing followed by PWHT with the TP of 18.3

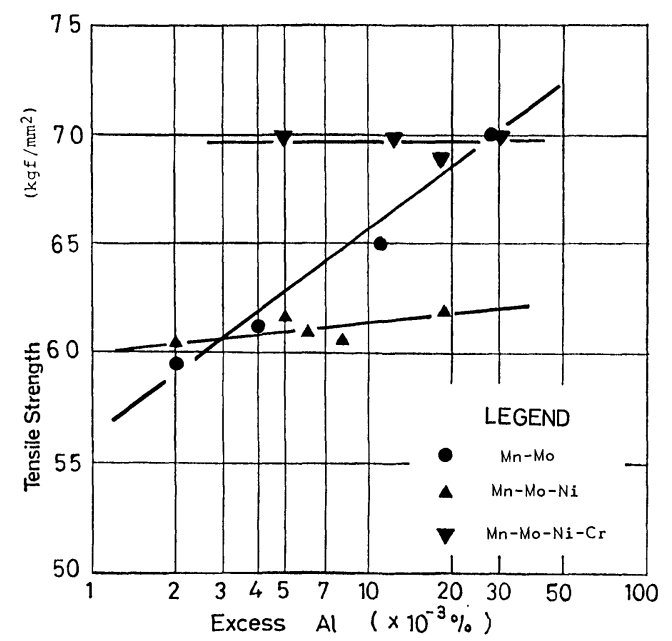

Fig. 1. Influence of excess $\mathrm{Al}$ on the tensile strength in $\mathrm{Mn}-$ Mo, Mn-Mo-Ni and Mn-Mo-Ni-Cr steels. but the latter had the cooling rate of $3{ }^{\circ} \mathrm{C} / \mathrm{min}$ in normalizing followed by PWHT with the TP of 19.2.

On the other hand, the FATT of Mn-Mo-Ni-Cr steel was distantly related to the excess $\mathrm{Al}$ in the present range as discussed later. It should be noted that the FATT of $\mathrm{Mn}-\mathrm{Mo}-\mathrm{Ni}-\mathrm{Cr}$ steel is clearly shown to be lower than that of Mn-Mo-Ni steel when comparing Fig. 6 with Fig. 7, notwithstanding their almost identical conditions in heat treatment as $\mathrm{Mn}$ Mo-Ni-Cr steel had the cooling rate of $3{ }^{\circ} \mathrm{C} / \mathrm{min}$ in normalizing followed by PWHT with the TP of 19.5.

Photograph 1 compares the austenitic grain sizes of heats with the highest excess $\mathrm{Al}$ and with the lowest excess $\mathrm{Al}$ in $\mathrm{Mn}-\mathrm{Mo}, \mathrm{Mn}-\mathrm{Mo}-\mathrm{Ni}$ and $\mathrm{Mn}-\mathrm{Mo}-\mathrm{Ni}-$ Cr steels. No difference at all in austenitic grain size was observed between heats with the highest excess $\mathrm{Al}$ and with the lowest excess $\mathrm{Al}$ in the three steels. It is then considered that the microstructure is more important than the austenitic grain size in the present case with regard to the effect of excess $\mathrm{Al}$ on mechanical properties.

The microstructures of heats with the highest excess $\mathrm{Al}$ and with the lowest excess $\mathrm{Al}$ in $\mathrm{Mn}-\mathrm{Mo}$, $\mathrm{Mn}-\mathrm{Mo}-\mathrm{Ni}$ and $\mathrm{Mn}-\mathrm{Mo}-\mathrm{Ni}-\mathrm{Cr}$ steels are shown in Photo. 2 in order to compare the effect of excess $\mathrm{Al}$. Heats $1 \mathrm{~A}$ and 2A, which contained the highest excess $\mathrm{Al}$ in $\mathrm{Mn}-\mathrm{Mo}$ and $\mathrm{Mn}-\mathrm{Mo}-\mathrm{Ni}$ steels, respectively, had the coarse structure of upper bainite with bainitic ferrite sideplates of Widmanstätten morphology (ferrite with an aligned martensite-austenite constituent), since excess $\mathrm{Al}$ tends to retard the ferrite transformation due to the rate control of $\mathrm{Al}$ partitioning in the ferritic component of bainite and expels $\mathrm{G}$ from bainitic ferrite sideplates into retained austenite left between them as they grow during continuous-cooling-
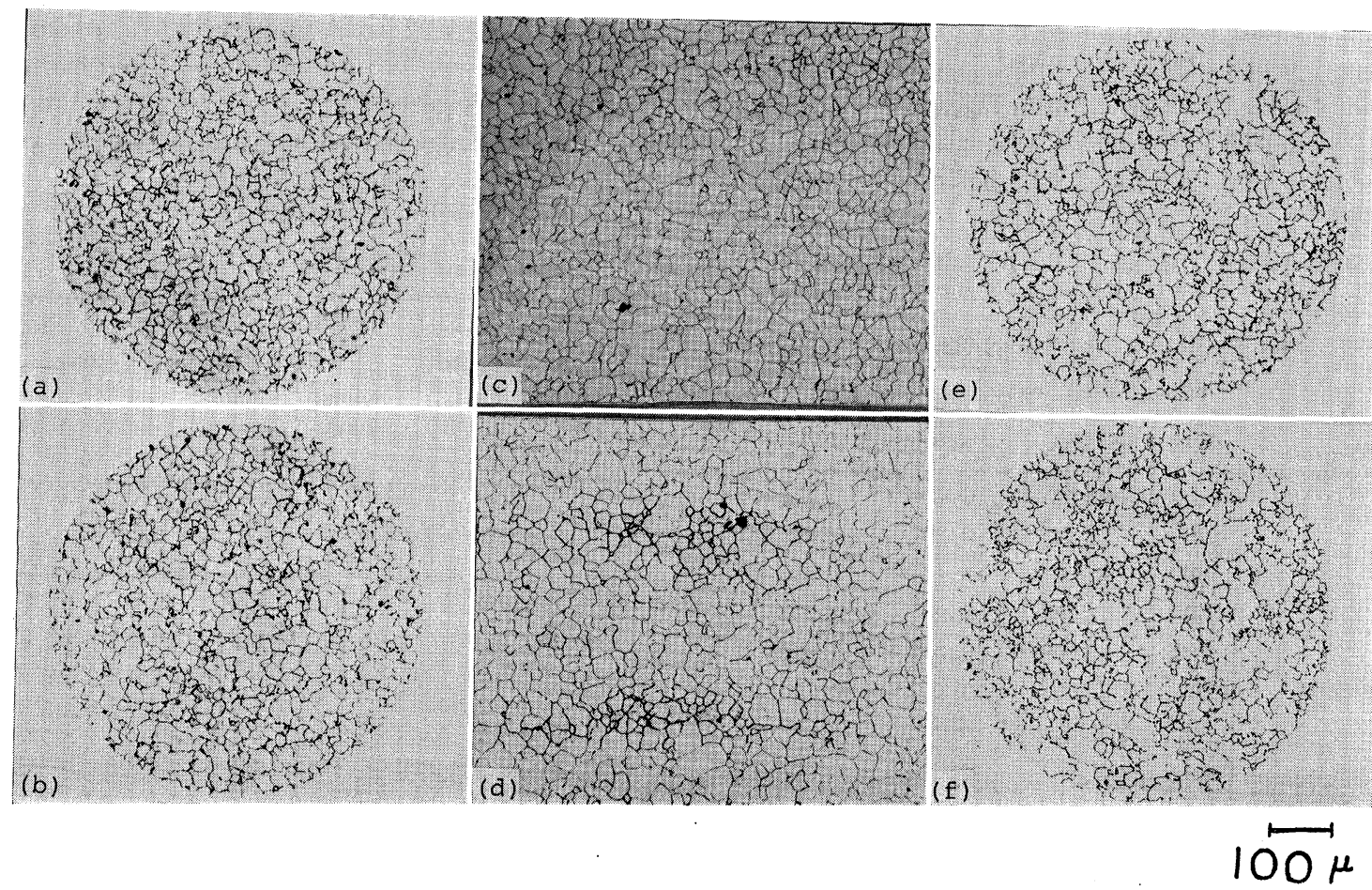

Photo. 1. Austenitic grains of the three steels in the order: (a) Heat 1A, (b) Heat 1D, (c) Heat 2A, (d) Heat 2E, (e) Heat 3A and (f) Heat 3D containing (a) (c) (e) the highest excess $\mathrm{Al}$ and (b) (d) (f) the lowest excess $\mathrm{Al}$ in the three steels. 
transformation due to a repulsive force between Al-C. It is also important to note that the grain size of upper bainite in Heats $1 \mathrm{~A}$ and $2 \mathrm{~A}$ corresponded almost to the grain size of the prior austenite, grain boundaries of which were clearly etched by $5 \%$ nital.

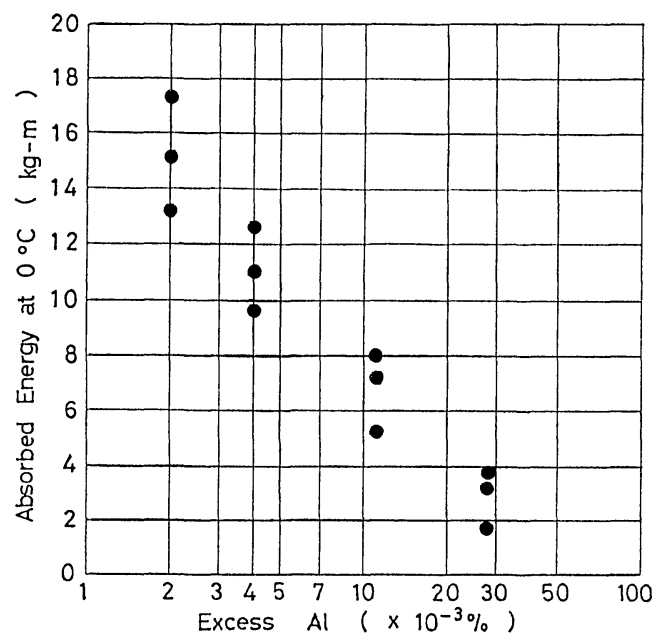

Fig. 2. Effect of excess $\mathrm{Al}$ on the absorbed energy of $\mathrm{Mn}$ Mo steel in GVN impact tests at $0{ }^{\circ} \mathrm{C}$.

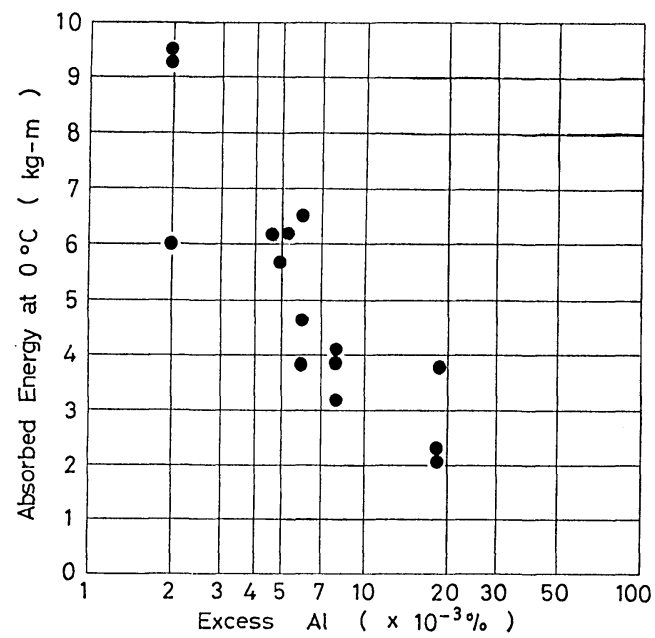

Fig. 3. Effect of excess $\mathrm{Al}$ on the absorbed energy of $\mathrm{Mn}$ Mo-Ni steel in GVN impact tests at $0{ }^{\circ} \mathrm{C}$.

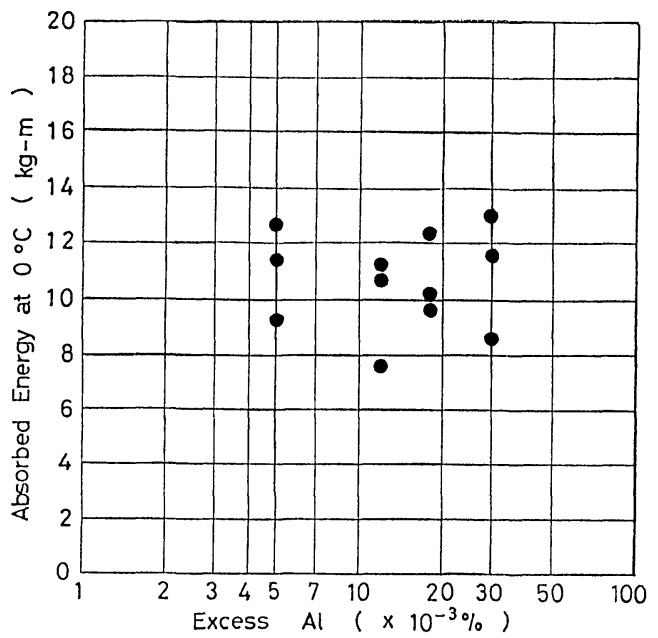

Fig. 4. Effect of excess $\mathrm{Al}$ on the absorbed energy of Mn$\mathrm{Mo}-\mathrm{Ni}-\mathrm{Cr}$ steel in $\mathrm{CVN}$ impact tests at $0^{\circ} \mathrm{C}$.
On the other hand, Heats $1 \mathrm{D}$ and 2E, which contained the lowest excess $\mathrm{Al}$ in $\mathrm{Mn}-\mathrm{Mo}$ and $\mathrm{Mn}-\mathrm{Mo}-$ $\mathrm{Ni}$ steels, respectively, had a fine allotriomorphic structure of ferrite at the grain boundaries of the prior austenite, an idiomorphic structure of ferrite blocks

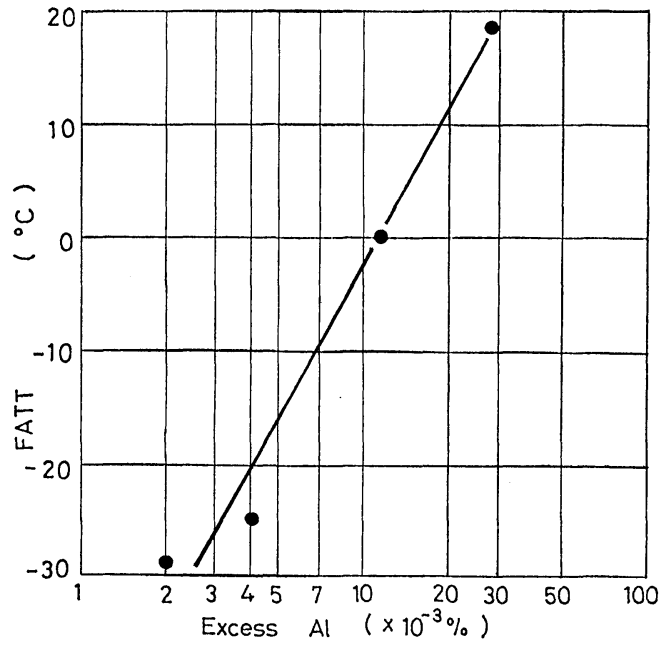

Fig. 5. Correlation of the FATT in GVN impact tests with the excess $\mathrm{Al}$ in $\mathrm{Mn}-\mathrm{Mo}$ steel.

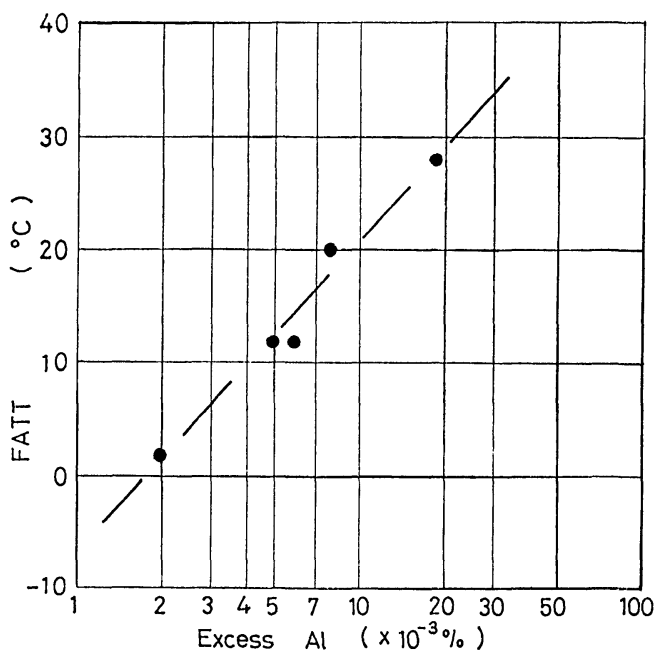

Fig. 6. Correlation of the FATT in CVN impact tests with the excess $\mathrm{Al}$ in $\mathrm{Mn}-\mathrm{Mo}-\mathrm{Ni}$ steel.

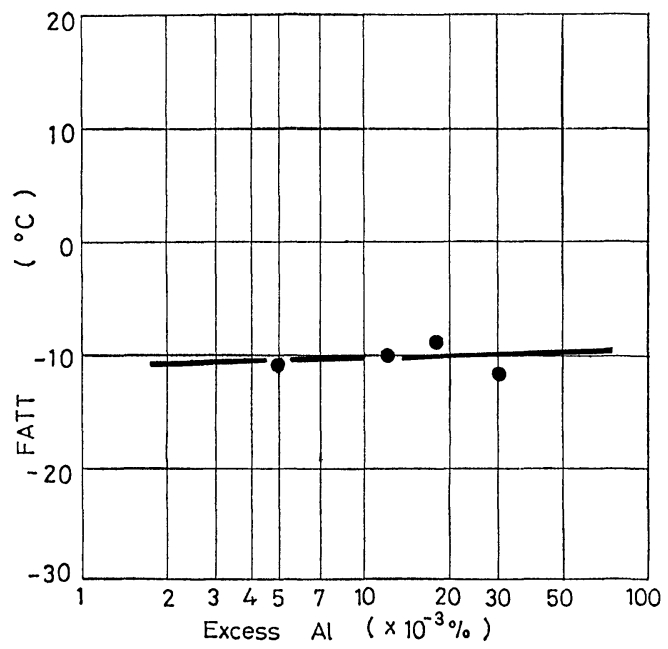

Fig. 7. Correlation of the FATT in CVN impact tests with the excess $\mathrm{Al}$ in $\mathrm{Mn}-\mathrm{Mo}-\mathrm{Ni}-\mathrm{Cr}$ steel. 

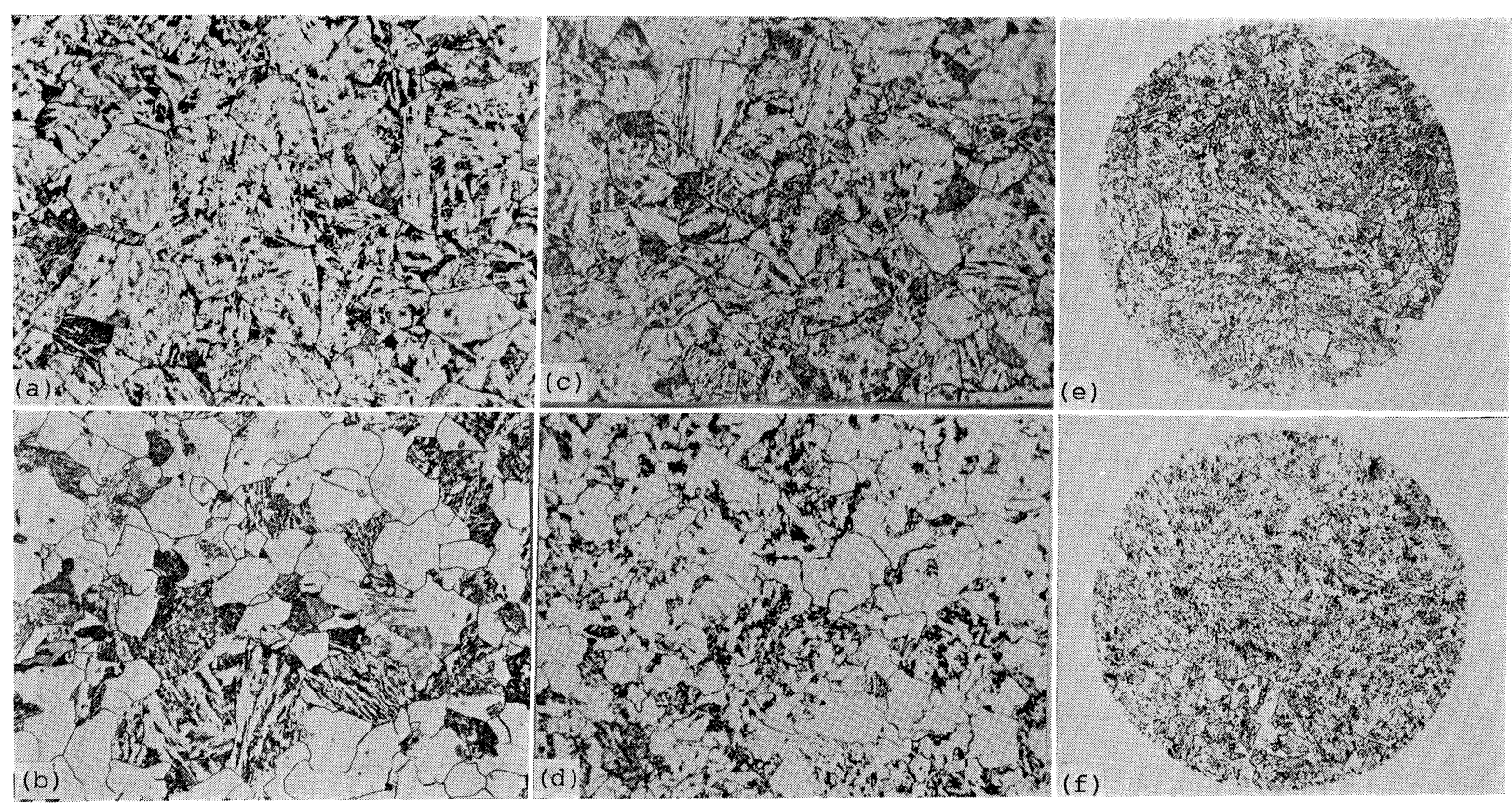

$25 \mu$

Photo. 2. Microstructure of the three steels in the order: (a) Heat 1A, (b) Heat 1D, (c) Heat 2A, (d) Heat 2E, (e) Heat $3 \mathrm{~A}$ and (f) Heat $3 \mathrm{D}$ containing (a) (c) (e) the highest excess $\mathrm{Al}$ and (b) (d) (f) the lowest excess $\mathrm{Al}$ in the three steels.

inside the prior austenitic grains, and a partly developed upper bainitic structure. It is also noted that the structure in Heats 1D and 2E appears to be finer than that in Heats $1 \mathrm{~A}$ and $2 \mathrm{~A}$, although the difference in austenitic grain size was not observed as shown in Photo. 1. It seems then that the influence of excess $\mathrm{Al}$ on mechanical properties in $\mathrm{Mn}-\mathrm{Mo}$ and $\mathrm{Mn}-$ Mo-Ni steels is to change the microstructure from mostly fine ferrite to coarse upper bainite.

It follows in Photo. 2 that Heats $3 \mathrm{~A}$ and $3 \mathrm{D}$ in $\mathrm{Mn}-\mathrm{Mo}-\mathrm{Ni}-\mathrm{Cr}$ steel had the fine structure of lower bainite without regard to the amount of excess $\mathrm{Al}$, since $\mathrm{Ni}$ and $\mathrm{Cr}$ seem to weaken the influence of excess $\mathrm{Al}$ on the change of microstructure through the reduction of $\mathrm{Al}$ partitioning in the ferritic component of bainite. This is due to attractive forces between $\mathrm{Al}-\mathrm{Ni}$ and $\mathrm{Al}-\mathrm{Cr}$, and also $\mathrm{Cr}$ appears to retard pearlite transformation due to the rate control of $\mathrm{Cr}$ partitioning in cementite, as discussed later.

The fracture mode of GVN impact specimens tested at $-20^{\circ} \mathrm{C}$ for Heats $2 \mathrm{~A}$ and $2 \mathrm{E}$ in $\mathrm{Mn}-\mathrm{Mo}-\mathrm{Ni}$ steel is shown in the previous report ${ }^{7)}$ to compare the effects of excess Al. It is reported that Heat 2A, which contained the highest excess $\mathrm{Al}$ of $0.019 \%$ in the Mn-Mo-Ni steel, showed almost complete transgranular cleavage, while Heats 2E, from which excess $\mathrm{Al}$ was almost removed, showed microvoid coalescence in the initiation region and transgranular cleavage in the propagation region. These observations correspond well with the former experimental results that sufficient excess $\mathrm{Al}$ would result the prevention of microvoid coalescence, which could absorb higher energy than cleavage, on account of the change of microstructure from mostly fine ferrite to coarse upper bainite.
It is also shown in Fig. 8, which depicts the continuous-cooling-transformation diagram for $\mathrm{Mn}-\mathrm{Mo}-$ $\mathrm{Ni}$ steels with the highest excess $\mathrm{Al}$ and with the lowest excess $\mathrm{Al}$, that excess $\mathrm{Al}$ in the austenite tends to retard proeutectoid ferrite and to develop upper bainite with bainitic ferrite sideplates. It should be noted that these results can explain the foregoing experimental observations.

\section{Discussion}

It is clearly demonstrated in the results of the present study that the excess $\mathrm{Al}$ in $\mathrm{Mn}-\mathrm{Mo}$ (A302B) steel considerably reduces the low-temperature toughness and increases drastically the tensile strength. The influence of excess $\mathrm{Al}$ in the steel on mechanical properties appears to be due to the change in the microstructure of the steel from mostly fine ferrite to coarse upper bainite. It is also shown in $\mathrm{Mn}-\mathrm{Mo}-$ $\mathrm{Ni}$ (A302C) steel that an addition of $\mathrm{Ni}$ can moderate the influence of excess $\mathrm{Al}$ in the steel on mechanical properties, above all, on the tensile strength.

On the other hand, it is noted in $\mathrm{Mn}-\mathrm{Mo}-\mathrm{Ni}$ $\mathrm{Cr}$ (A302C-Cr Mod.) steel that additions of $\mathrm{Ni}$ and $\mathrm{Cr}$ almost eliminate the influence of excess $\mathrm{Al}$ in the present range on mechanical properties.

Hence, discussions of the foregoing results in the present study are focussed on the mechanism of the changes in microstructures of the three steels with assistance of ideas on solute interactions in a ternary solid solution and on partitioning of alloying elements during continuous-cooling-transformation.

\section{Influence of Solute Interactions in Steel}

The interaction parameter $\varepsilon_{B}^{(\text {) }}$, which shows the solute interaction between elements $\mathrm{B}$ and $\mathrm{C}$ in a 


\begin{tabular}{c|cc}
\hline Heat & $2 \mathrm{~A}$ & $2 \mathrm{E}$ \\
\cline { 2 - 3 } Mark & -- & \\
\hline$A_{\mathrm{c} 1}\left({ }^{\circ} \mathrm{C}\right)$ & 730 & 840 \\
$A_{\mathrm{c} 3}\left({ }^{\circ} \mathrm{C}\right)$ & 720 & 830 \\
\hline
\end{tabular}

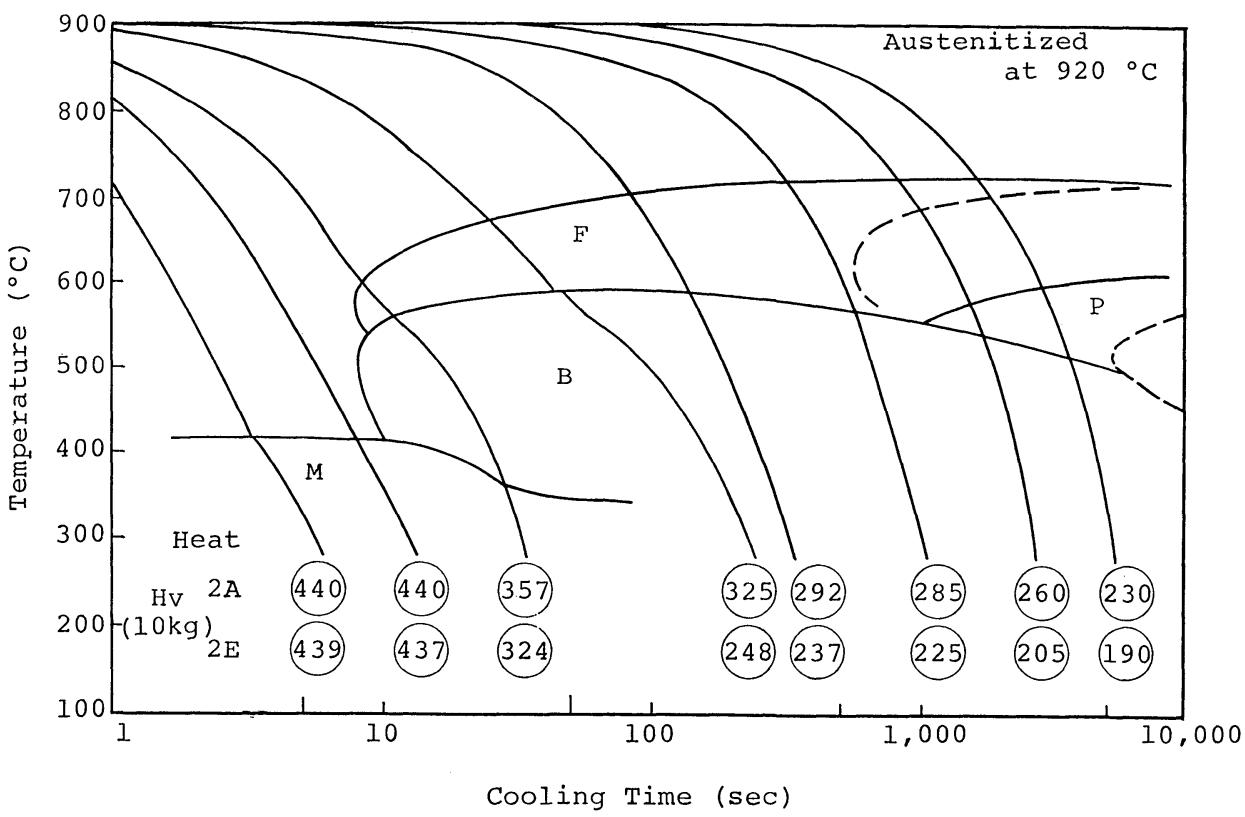

Fig. 8. Continuous-cooling-transformation diagram for Mn-Mo-Ni steels with the highest excess $\mathrm{Al}$ (Heat 2A) and with the lowest excess Al (Heat 2E).

ternary solid solution for an $\mathrm{A}-\mathrm{B}-\mathrm{C}$ system with $\mathrm{A}$ as solvent, is defined as the following equation. ${ }^{10,12)}$

$$
\varepsilon_{\mathrm{B}}^{(\mathrm{C})}=\alpha_{\mathrm{BC}}-\alpha_{\mathrm{AB}}-\alpha_{\mathrm{CA}}
$$

where, $\alpha_{i j}$ : the interaction parameter in a binary solid solution for an $i-j$ system as defined in the quasi-chemical equation.

$\alpha_{i j}=Z \mathcal{N}\left[\Omega_{i j}-1 / 2\left(\Omega_{i i}+\Omega_{j j}\right)\right]$

where, $Z:$ the coordination number in the lattice

$\mathcal{N}:$ Avogadro's number

$\Omega_{i j}:$ the binding energy of an $i-j$ bond in the lattice.

Thus, the solid solution tends to order in the short range or to form compounds due to an attractive force between $i-j$ when $\alpha_{i j}<0$. In turn, the solid solution tends to cluster in like atoms due to a repulsive force between $i-j$ when $\alpha_{i j}>0$.

The above interpretation would imply that $\alpha_{i j}$ can qualitatively be predicted with the assistance of the published phase diagrams. ${ }^{11)}$ It is also connoted that the interaction parameter $\varepsilon_{B}^{(G)}$ in a ternary solid solution can have the same influence on an attractive force or on a repulsive force as the interaction parameter $\alpha_{i j}$ in a binary solid solution.

Equations (3) and (4) are generally expressed in the whole range of a ternary solid solution for an A-B-C system with $\mathrm{A}$ as solvent, but the present interest in this study is to know the influence of solute interactions in practical steel. Hence, Eq. (3) is changed to the following.

$$
\varepsilon_{\mathrm{B}}^{(\mathrm{C})}=\alpha_{\mathrm{BC}}-\alpha_{\mathrm{FeB}}-\alpha_{\mathrm{CFe}}
$$

where, $\varepsilon_{B}^{(C)}$ : the interaction parameter of $\mathrm{B}$ and $\mathrm{G}$ dissolved in steel for the $\mathrm{Fe}-\mathrm{B}-\mathrm{C}$ system.

By the introduction of Eq. (5), attractive forces in steel between $\mathrm{Si}-\mathrm{Mn}, \mathrm{Ni}-\mathrm{Al}, \mathrm{Ni}-\mathrm{Si}, \mathrm{Cr}-\mathrm{Si}$ and $\mathrm{Cr}-$ $\mathrm{Al}$ due to $\varepsilon_{\mathrm{B}}^{(\mathrm{C})}<0$ and a repulsive force in steel between $\mathrm{Al}-\mathrm{Si}$ due to $\varepsilon_{\mathbf{B}}^{(\mathrm{C})}>0$ can qualitatively be predicted with the assistance of phase diagrams on stable intermetallic compounds.11) This prediction is confirmed by the cosegregations of $\mathrm{Si}-\mathrm{Mn}, \mathrm{Ni}-\mathrm{Al}^{9)}$ and $\mathrm{Ni}-\mathrm{Si}^{9,16)}$ in a $5 \% \mathrm{Ni}$ steel, by the cosegregation of $\mathrm{Cr}-\mathrm{Si}$ in a $2 \cdot 1 / 4 \% \mathrm{Cr}-1 \% \mathrm{Mo}$ steel, ${ }^{17)}$ and by the site competition of $\mathrm{Al}-\mathrm{Si}$ in a $5 \% \mathrm{Ni}$ steel with high $\mathrm{Al}^{9)}$ at grain boundaries.

Very little effort has been spent in understanding continuous-cooling-transformation with regard to solute interactions and in obtaining the interaction parameters $\varepsilon_{\mathbf{B}}^{(\mathrm{C})}$ dissolved in austenite and ferrite due to experimental difficulties. However, Mori and Ichise ${ }^{13)}$ studied the correlation between interaction coefficients, which are equal to interaction parameters over $R T$,* of nitrogen dissolved in liquid iron and in austenite for $\mathrm{Fe}-\mathrm{N}-\mathrm{X}$ systems. It implies that the interaction coefficient in austenite can be supposed by the interaction coefficient in liquid iron. It is also noted in the same results ${ }^{13)}$ that repulsive forces are held between $\mathrm{Si}-\mathrm{N}, \mathrm{P}-\mathrm{N}$ and $\mathrm{Ni}-\mathrm{N}$ due to $\varepsilon_{\mathrm{N}}^{(\mathrm{S})}>0$, while attractive forces are held between $\mathrm{Cr}-\mathrm{N}, \mathrm{Mo}-\mathrm{N}$ and $\mathrm{Mn}-\mathrm{N}$ due to $\varepsilon_{\mathrm{N}}^{(\mathrm{X})}<0$. This supposition is confirmed by the site competition of $\mathrm{P}-\mathrm{N}$ in grain boundary segregation at $600^{\circ} \mathrm{C}$ for the $\mathrm{Fe}-\mathrm{P}-\mathrm{N}$ system ${ }^{31}$ ) and by the enhanced segregation of $\mathrm{N}$ at grain boundaries due to a repulsive force with $\mathrm{Si}$, in bulk, during short-time ageing in a $5 \% \mathrm{Ni}$ steel. $\left.{ }^{9}\right)$

The sufficient data on interaction coefficients $\varepsilon_{\mathrm{B}}^{(\mathrm{C})}$, which were employed for $\mathrm{Fe}-\mathrm{N}-\mathrm{X}$ systems, for dilute solutions of elements $\mathrm{B}$ and $\mathrm{C}$ dissolved in liquid iron at $1600{ }^{\circ} \mathrm{C}$ were summarized by Elliott et al. ${ }^{14)}$ The foregoing prediction of repulsive force between $\mathrm{Al}-\mathrm{Si}$ by Eq. (5) is also supported by the interaction coefficient of $\mathrm{Al}$ and $\mathrm{Si}$ dissolved in liquid iron as

* $R:$ gas constant, $T:$ temperature $(\mathrm{K})$ 
shown by Elliott et al. ${ }^{14)}$

It is of particular interest that the interaction coefficients of carbon, dissolved in liquid iron at $1550{ }^{\circ} \mathrm{C}$ for $\mathrm{Fe}-\mathrm{C}-\mathrm{M}$ systems shift periodically along with atomic number. ${ }^{12,15)}$

On the other hand, Bain ${ }^{1)}$ reported the tendency to form carbides of various alloying elements in steels as following.

$$
\begin{aligned}
\mathrm{Ti} & >\mathrm{Zr}>\mathrm{Nb}>\mathrm{V}>\mathrm{Ta}>\mathrm{W}>\mathrm{Mo}>\mathrm{Gr} \\
& >\mathrm{Mn}>(\mathrm{Fe})>\mathrm{Ni}>\mathrm{Co}>\mathrm{Gu}>\mathrm{Al}>\mathrm{Si} \ldots \ldots(6)
\end{aligned}
$$

where $(\mathrm{Fe})$ indicates the solvent for $\mathrm{Fe}-\mathrm{C}-\mathrm{M}$ systems.

It is remarkably interesting to note in the comparison of the foregoing results ${ }^{12,15)}$ with Eq. (6) that the values on the interaction coefficients of carbon correspond well with the tendency to form carbides in Eq. (6). It is again implied that the interaction coefficient in steel can qualitatively be supposed by the interaction coefficient in liquid iron. Thus, it is considered that elements on the right hand side of $(\mathrm{Fe})$ in Eq. (6) can not form their carbides in steel since repulsive forces take place between $\mathrm{Si}-\mathrm{C}, \mathrm{Al}-\mathrm{C}$ and so on due to $\varepsilon_{\mathrm{C}}^{(\mathrm{M})}>0$, while elements on the left hand side of $(\mathrm{Fe})$ in Eq. (6) have attractive forces with $\mathrm{G}$ due to $\varepsilon_{\mathrm{C}}^{(\mathrm{MI})}<0$. This prediction would suggest that $\mathrm{Al}$ as well as $\mathrm{Si}$ raises the activity of carbon in ferrite as also shown by Bain. ${ }^{1)}$ The repulsive force between $\mathrm{Si}-\mathrm{C}$ for the $\mathrm{Fe}-\mathrm{C}-\mathrm{Si}$ system was first demonstrated by Darken ${ }^{2)}$ in the study of uphill diffusion. The repulsive force between $\mathrm{Al}-\mathrm{C}$ was confirmed by the studies of $\mathrm{Al}$ partitioning in an $\mathrm{A} 302 \mathrm{C}$ steel ${ }^{7)}$ and in a dual-phase steel with $1 \% \mathrm{Al}^{18)}$

The repulsive force between $\mathrm{P}-\mathrm{G}$, which can be predicted by interaction coefficients in liquid iron, ${ }^{12,15)}$ is supported by the studies on the banded structure of ferrite and pearlite ${ }^{3,4)}$ and on the site competition of $\mathrm{P}-\mathrm{C}$ in grain boundary segregation for the $\mathrm{Fe}-\mathrm{P}-$ C system. ${ }^{31}$

It is consequently confirmed that the tendency to form compounds between metalloid and alloying elements is to be significantly useful in predicting solute interactions in steel.

Kaneko et al. ${ }^{22)}$ reported the tendency to form phosphides of various alloying elements in steel as following.

$$
\begin{aligned}
& \mathrm{Mo}>\mathrm{Nb}>\mathrm{Zr}>\mathrm{Ti}>\mathrm{V}>\mathrm{Gr}>\mathrm{Mn}>\mathrm{W} \\
& >\mathrm{Ni}>(\mathrm{Fe})>\mathrm{Co}>\mathrm{Si}>\mathrm{Al}
\end{aligned}
$$

where $(\mathrm{Fe})$ indicates the solvent for $\mathrm{Fe}-\mathrm{P}-\mathrm{M}$ systems. Aluminum and $\mathrm{Si}$ on the right hand side of $(\mathrm{Fe})$ in Eq. (7) can not form their phosphides in steel since repulsive forces take place between $\mathrm{Al}-\mathrm{P}$ and $\mathrm{Si}-\mathrm{P}$. The repulsive force between $\mathrm{Si}-\mathrm{P}$ is confirmed by the interaction coefficient of $\mathrm{P}$ and $\mathrm{Si}$ by Elliott $e t$ al., ${ }^{14}$ by the enhanced segregation of $\mathrm{P}$ at grain boundaries due to repulsive force with $\mathrm{Si}$, in bulk in a $2 \cdot 1 / 4 \% \mathrm{Cr}$ $1 \%$ Mo steel ${ }^{25)}$ and in a $5 \%$ Ni steel, ${ }^{9}$ and by the Uturn behavior of $\mathrm{P}$ in accordance with the accumulation of segregated $\mathrm{Si}$ at grain boundaries in a $5 \% \mathrm{Ni}$ steel. ${ }^{\text {9) }}$

It is considered that an attractive force between
Mo-P is preferred to that between Mo-C in practical steel because of the difference in the orders of Mo in Eqs. (6) and (7) to indicate the affinity of Mo with $\mathrm{C}$ or $\mathrm{P}$. The above prediction is supported by the fact that the addition of Mo acts to inhibit P-induced temper embrittlement in the series of $\mathrm{Mn}-\mathrm{Ni}-\mathrm{Cr}-\mathrm{Mo}$ steel, ${ }^{24)}$ confirmed by Mo apparently being able to act as an effective scavenger and preventing $P$ segregation to grain boundaries until the precipitation of Mo carbides in a $3.5 \% \mathrm{Ni}-1.7 \% \mathrm{Cr}$ steel, ${ }^{19)}$ and also proved by the fact that the addition of Mo in the range of 0.5 to $0.7 \%$ can diminish $\mathrm{P}$ segregation until Mo precipitation $\mathrm{As} \mathrm{M}_{2} \mathrm{C}$ in $2 \cdot 1 / 4 \% \mathrm{Cr}$ steels. ${ }^{17)}$

It is also predicted by Eq. (7) that attractive forces can be established between $\mathrm{Mn}-\mathrm{P}, \mathrm{Cr}-\mathrm{P}$ and presumably Ni-P. The attractive force between Mn-P is confirmed by the cosegregations of $\mathrm{Mn}-\mathrm{P}$ in the austenite region of a $3.5 \% \mathrm{Ni}-1.5 \% \mathrm{Cr}$ steel ${ }^{20)}$ and in a $2 \cdot 1 / 4 \% \mathrm{Cr}-1 \%$ Mo steel. ${ }^{25)}$ The attractive force between $\mathrm{Cr}-\mathrm{P}$ is demonstrated by the cosegregation of $\mathrm{Cr}-\mathrm{P}$ after the Mo carbide of $\mathrm{M}_{2} \mathrm{C}$ is formed at the expense of $\mathrm{Cr}$-rich $\mathrm{M}_{7} \mathrm{C}_{3}$ in $2.1 / 4 \% \mathrm{Cr}$ steels, ${ }^{17)}$ and by the cosegregation of $\mathrm{Cr}-\mathrm{P}$ in a $3.5 \% \mathrm{Ni}-1.7 \% \mathrm{Cr}$ steel. ${ }^{21)}$ The attractive force between $\mathrm{Ni}-\mathrm{P}$ is also shown by the cosegregation of $\mathrm{Ni}-\mathrm{P}$ in a $3.5 \% \mathrm{Ni}-$ $1.7 \% \mathrm{Cr}$ steel. ${ }^{21)}$

However, it appears that the other elements on the left hand side of (Fe) in Eq. (7) may not effectively interact with $\mathrm{P}$ in steels due to the strong affinities with $\mathrm{C}, \mathrm{N}, \mathrm{O}$ or $\mathrm{S}$.

It is then offered that the change in microstructures during continuous-cooling-transformation as well as the segregation of alloying elements and impurities at grain boundaries can be due to the resultant interactions of attractive forces between $\mathrm{Ni}-\mathrm{Al}, \mathrm{Ni}-\mathrm{Si}, \mathrm{Cr}-\mathrm{Si}$, $\mathrm{Cr}-\mathrm{Al}, \mathrm{Cr}-\mathrm{N}, \mathrm{Ni}-\mathrm{P}, \mathrm{Mo}-\mathrm{P}, \mathrm{Mn}-\mathrm{P}, \mathrm{Cr}-\mathrm{P}$ and so on, and of repulsive forces between $\mathrm{Al}-\mathrm{Si}, \mathrm{Si}-\mathrm{C}, \mathrm{Al}-\mathrm{C}$, $\mathrm{P}-\mathrm{C}, \mathrm{Si}-\mathrm{P}, \mathrm{Al}-\mathrm{P}, \mathrm{Si}-\mathrm{N}, \mathrm{P}-\mathrm{N}$ and so on, as shown by previous works. ${ }^{7,9)}$

It is eventually rationalized through the present discussions that the solute interactions of a repulsive force between $\mathrm{Al}-\mathrm{C}$ and of attractive forces between $\mathrm{Al}-\mathrm{Ni}$ and presumably $\mathrm{Al}-\mathrm{Cr}$ are of particular importance in addition to the influences of $\mathrm{Al}$ partitioning in ferrite and of $\mathrm{Cr}$ partitioning in cementite in considering the mechanism on the change of microstructure in the three steels with regard to excess $\mathrm{Al}$ as summarized below.

(1) Aluminum, which partitions proeutectoid ferrite (or the ferritic component of bainite), ${ }^{7,18)}$ rejects $\mathrm{C}$ into austenite due to a repulsive force between Al-C at higher temperature, and then the retained austenite left between bainitic ferrite tends to contain higher $\mathrm{C}$ concentrations during continuous-coolingtransformation. Finally, Mn-Mo (A302B) steel with high excess $\mathrm{Al}$ develops into mixed structures of mostly upper bainite and high carbon martensite-austenite constituent left between bainitic ferrite.

(2) Aluminum partitioning in the ferrite-phase can be weakened by Ni due to an attractive force between $\mathrm{Al}-\mathrm{Ni}$ in the austenite of $\mathrm{Mn}-\mathrm{Mo}-\mathrm{Ni}$ (A302C) steel. Thus, Ni appears to decrease the influence of 
excess $\mathrm{Al}$ on mechanical properties through the change in microstructure, since $\mathrm{C}$ enrichment into retained austenite left bainitic ferrite during continuous-cooling-transformation is indirectly lowered by the reduction of $\mathrm{Al}$ partitioning in the steel.

(3) Ghromium in Mn-Mo-Ni-Cr (A302C-Cr Mod.) steel appears to have two kinds of role in considering the influence of excess $\mathrm{Al}$. Cr seems to have the same effect as $\mathrm{Ni}$ to weaken $\mathrm{Al}$ partitioning due to an attractive force between $\mathrm{Al}-\mathrm{Cr}$ in austenite, while the other is on $\mathrm{Cr}$ partitioning in cementite to retard pearlite transformation as discussed later. However, the latter is considered to be more important than the former, since the steel consists not of fine allotriomorphic at grain boundaries but of lower bainite in $\mathrm{Mn}$ Mo-Ni-Cr steel.

\section{Influence of Solute Partitioning in Steel}

Sato and Nishizawa ${ }^{23)}$ investigated the partitioning parameter of alloying elements in cementite or in ferrite for $\mathrm{Fe}-\mathrm{C}-\mathrm{M}$ systems, except for $\mathrm{Al}$. The tendency to form carbides in Eq. (6) does not correspond well with the tendency to partition cementite ${ }^{23)}$ since $\mathrm{Cr}$ and $\mathrm{Mn}$ can form stable carbides as $(\mathrm{Fe}, \mathrm{M})_{3} \mathrm{C}$ but other elements tend to form their own stable carbides as MG. The retardation of pearlite transformation can take place due to the rate control of $\mathrm{Cr}$ partitioning between austenite and cementite as shown by previous investigators. ${ }^{26-28)}$

J. Y. Koo et al. ${ }^{18)}$ studied $\mathrm{Al}$ partitioning in the dual-phase steel of AISI 1010 with $1 \% \mathrm{Al}$ and $0.10 \% \mathrm{C}$. They reported that Al partitioned ferrite two times higher than martensite and in turn carbon partitioned martensite in the range of 0.50 to $0.65 \%$. The $\mathrm{Al}$ partitioning parameter of at most 0.1 is derived from the hypothesis that the partitioning parameter of $\mathrm{Al}$ is $1 / 2$ in martensite over that in ferrite and the partitioning parameter of $\mathrm{Al}$ is at most $1 / 5$ in cementite over that in the ferritic component of martensite employing the above data. ${ }^{18)}$ The foregoing hypothesis is quite consistent with the previous data on the partitioning parameter by Hultgren. ${ }^{32,33)}$

Aluminum tends to retard ferrite transformation due to the rate control of $\mathrm{Al}$ partitioning between austenite and proeutectoid ferrite as is clearly shown in Fig. 8. It is also supported by Yoshimura and Kobayashi ${ }^{29)}$ that $\mathrm{Al}$ dissolved in austenite tends to retard the ferrite transformation resulting in a mostly upper bainitic structure in a $1 \% \mathrm{Cr}-0.2 \%$ Mo steel, although the above mechanism is not explained.

On the other hand, Ito et al. ${ }^{30)}$ observed in a $1.5 \% \mathrm{Ni}-0.7 \% \mathrm{Cr}-0.5 \% \mathrm{Mo}-15 \mathrm{ppmB}$ steel that Si promoted upper bainite, which consisted of a bainitic ferrite plates and martensite-austenite constituent left between them. They attributed this effect of Si to the low partitioning of $\mathrm{Si}$ in cementite as shown by previous investigators. ${ }^{23,32)}$ However, it seems better to explain that the above result can be due to the rate control of $\mathrm{Si}$ partitioning in the ferritic component of bainite and due to the raise of $\mathrm{G}$ activity in the ferrite-phase resulting in the change of carbide morphology and in $\mathrm{C}$ enrichment into retain- ed austenite left between bainitic ferrite plates during transformation through a repulsive force between $\mathrm{Si}-\mathrm{C}$.

It is now possible with the assistance of a partitioning parameter to discuss the $\mathrm{Al}$ partitioning in the ferrite-phase and the $\mathrm{Cr}$ partitioning in the cementite in the three steels as below.

(1) Excess $\mathrm{Al}$ partitions proeutectoid ferrite (or the ferritic component of bainite) to retard ferrite transformation resulting in an upper bainitic structure with the assistance of $\mathrm{G}$ enrichment into retained austenite left between bainitic ferrite plates during transformation due to a repulsive force between $\mathrm{Al}-\mathrm{C}$ in $\mathrm{Mn}-\mathrm{Mo}$ and $\mathrm{Mn}-\mathrm{Mo}-\mathrm{Ni}$ steels.

(2) Chromium partitions the cementitic component of bainite to retard pearlite (or upper bainite) transformation resulting in lower bainitic structure with assistance of the reduction of $\mathrm{Al}$ partitioning due to attractive forces between $\mathrm{Al}-\mathrm{Ni}$ and $\mathrm{Cr}-\mathrm{Ni}$, in $\mathrm{Mn}-$ Mo-Ni-Cr steel.

\section{Conclusions}

The influence of excess $\mathrm{Al}$ in $\mathrm{Mn}-\mathrm{Mo}, \mathrm{Mn}-\mathrm{Mo}-\mathrm{Ni}$ and $\mathrm{Mn}-\mathrm{Mo}-\mathrm{Ni}-\mathrm{Cr}$ steels on mechanical properties have been studied with regard to solute interactions in solid solution and to partitioning of alloying elements. It is clearly shown in this study that the excess $\mathrm{Al}$ of $\mathrm{Mn}-\mathrm{Mo}$ and $\mathrm{Mn}-\mathrm{Mo}-\mathrm{Ni}$ steels deteriorates the lowtemperature toughness and increases the tensile strength due to the change in microstructure form mostly fine ferrite to coarse upper bainite, although the influence of excess $\mathrm{Al}$ in the latter steel is weakened more than that in the former steel, whereas the excess $\mathrm{Al}$ of $\mathrm{Mn}-\mathrm{Mo}-\mathrm{Ni}-\mathrm{Cr}$ steel does not relate both to the low-temperature toughness and to the tensile strength. The mechanisms of the foregoing results are considered due to the following:

(1) Excess $\mathrm{Al}$ in austenite tends to partition proeutectoid ferrite (or the ferritic component of bainite) and to retard ferrite transformation because of the rate control of $\mathrm{Al}$ partitioning during continuouscooling-transformation.

(2) Retained austenite left between the bainitic ferrite has a higher $\mathrm{G}$ concentration during transformation, since $\mathrm{Al}$ in the bainitic ferrite rejects $\mathrm{C}$ into austenite due to a repulsive force between $\mathrm{Al}-\mathrm{C}$ at higher temperature.

(3) Finally, the microstructure of $\mathrm{Mn}-\mathrm{Mo}$ and Mn-Mo-Ni steels with high excess $\mathrm{Al}$ develops (from fine ferrite) into mixed structures of mostly upper bainite and high carbon bainite (or a martensite-austenite constituent).

(4) Aluminum partitioning in the ferrite-phase is weakened by $\mathrm{Ni}$ due to an attractive force between $\mathrm{Al}-\mathrm{Ni}$ in austenite resulting in the reduction of $\mathrm{C}$ enrichment into retained austenite left bainitic ferrite plates during transformation, then the influence of excess $\mathrm{Al}$ on mechanical properties is lowered by an addition of $\mathrm{Ni}$ in $\mathrm{Mn}-\mathrm{Mo}-\mathrm{Ni}$ steel.

(5) Chromium in austenite tends to partition the cementitic component of bainite and to retard pearlite (or upper bainite) transformation because of the rate 
control of $\mathrm{Cr}$ partitioning during continuous-coolingtransformation, and $\mathrm{Al}$ partitioning in the ferrite-phase is also weakened by $\mathrm{Cr}$ due to an attractive force between $\mathrm{Al}-\mathrm{Cr}$ in austenite resulting in the microstructure of lower bainite, then the influence of excess Al on mechanical properties is eliminated by additions of $\mathrm{Ni}$ and $\mathrm{Cr}$ in a $\mathrm{Mn}-\mathrm{Mo}-\mathrm{Ni}-\mathrm{Cr}$ steel.

It is consequently concluded in this study that the change of microstructures can be brought about by a small addition of alloying elements due to the solute interactions during transformation, while the substantial change of morphologies is associated with the differences in the free energy between each phase as a function of concentrations of alloying elements and in cooling rates during continuous-cooling-transformation.

\section{Acknowledgements}

The authors gratefully acknowledge the many helpful discussions and comments during the preparations of this paper with Dr. R. Yamamoto, The University of Tokyo and also would like to thank Mr. Yamaguchi, Nagoya Works, NSC for his cooperation on the present experiments.

\section{REFERENCES}

1) E. C. Bain: Function of Alloying Element in Steels, ASM, Ohio, (1939), 242.

2) L. S. Darken: Trans. AIME, 180 (1949), 430.

3) P. G. Bastien: JISI, 10 (1957), 281.

4) G. F. Jatczak, D. J. Girardi and E. S. Rowland: Trans. ASM, 48 (1956), 279.

5) H. Mabuchi, H. Gokyu and H. Shima: Japanese Patent No. 50-43415, Applied on April 11, 1975.

6) H. Mabuchi, H. Nakao, Y. Tokunaga and T. Kikutake: Tetsu-to-Hagané, 62 (1976), S758.

7) H. Mabuchi and H. Nakao: Trans. ISIJ, 21 (1981), 495.

8) H. Mabuchi and C. J. McMahon, Jr: Proc. Japan Inst. of Metals 2nd Int'l Symposium, Hydrogen in Metals, JIM, Sendai, (1979), 441.

9) H. Mabuchi: Trans. ISIJ, 22 (1982), 967.
10) J. L. Meijering: Physical Chemistry of Metallic Solutions and Intermetallic Compounds, II, (1959), 5A.

11) M. Hansen, R. P. Elliott and F. Shunk: Constitution of Binary Alloys, McGraw Hill Book Co., New York, (1958).

12) T. Nishizawa: Bull. Japan Inst. Metals, 12 (1973), 401.

13) T. Mori and E. Ichise: J. Japan Inst. Metals, 32 (1968), 949.

14) J. F. Elliott, M. Gleiser and V. Pamakrishna: Thermochemistry for Steelmaking, II, Addison-Wesley Publishing Co., Mass., (1963), 564.

15) F. Neumann and H. Schenk: Arch. Eisenhüttenw., 30 (1959), 477.

16) G. L. Briant, H. C. Feng and G. J. McMahon, Jr.: Met. Trans., 9A (1978), 625.

17) J. Yu and C. J. McMahon, Jr.: Met. Trans., 11A (1980), 277.

18) J. Y. Koo, M. Raghavan and G. Thomas: Met. Trans., 11A (1980), 351.

19) G. J. McMahon, Jr., A. K. Gianelli and H. C. Feng: Met. Trans., 8A (1977), 1055.

20) J. Q. Clayton: Ph. D. Thesis, Univ. of Cambridge, (1976).

21) R. A. Mulford, C. J. McMahon, Jr., D. P. Pope and H. C. Feng: Met. Trans., 7A (1976), 1183.

22) H. Kaneko, T. Nishizawa and K. Tamaki: J. Japan Inst. Metals, 29 (1965), 159.

23) T. Sato and T. Nishizawa: J. Japan Inst. Metals, 19 (1955), 385.

24) R. H. Greaves and J. A. Jones: Iron Steel Inst., 111 (1925), 231.

25) J. Yu and G. J. McMahon, Jr.: Met. Trans., 11A (1980), 291.

26) E. G. Bain and H. W. Paxton: Alloying Elements in Steel, 2nd Ed., 3rd Rev., ASM, Ohio, (1966), 255.

27) N. A. Razik, G. W. Lorimer and N. Ridley: Met. Trans., 7A (1976), 209.

28) J. Ghance and N. Ridley: Met. Trans., 12A (1981), 1205.

29) M. Yoshimura and H. Kobayashi: The Special Steel, 29 (1980), No. 11, 36

30) Y. Ito, Y. Kunitake, M. Ikeda, H. Ohtani and Y. Komizo: Sumitomo Metals, 29 (1977), 395.

31) H. Erhart and H.J. Grabke: Script. Met, 15 (1981), 531.

32) A. Hultgren: Kungl. Svenska Vetenskapsakademiens Handlingar Ser. 4, 4 (1953), No. 3.

33) S. Takaishi: Fuji Seitetsu Giho, 13 (1964), 1. 